\title{
1 A Nordic research agenda on rape and sexual violence
}

\author{
May-Len Skilbrei, Kari Stefansen and \\ Marie Bruvik Heinskou
}

\section{Introduction}

How best to prevent and prosecute rape, and to protect its victims, is debated in countries across the world. Rape has also become a central topic in supranational forums such as the United Nations and the European Union and is something that mobilises transnational civil society organisations such as Amnesty International and Equality Now. The issue has also spurred engagement on an individual level, as is evident in how the \#MeToo movement that gained momentum in 2017 brought the world's attention to rape and other forms of sexual harm.

This high level of attention reflects both an increasing awareness of the harm of rape throughout the last few decades and real or perceived changes in the extent and characteristics of the phenomenon of rape. Several countries are currently experiencing an increase in reported cases of rape. Since increased attention towards and understanding of the phenomenon affect identification and people's willingness to report, this increase does not necessarily mean that more people are victimised than earlier. But it does make rape into a phenomenon that policy-makers have to address. The large numbers of reported cases and the notable gap between these cases and convictions are something that, together with the visibility of personal experiences of violation found in social media, are key to the current debates and to opportunities for action.

That rape and other forms of sexual harm are taken seriously is not only something that has arisen from current developments. This story has been a long time in the making. Following the publication of Susan Brownmiller's radical interpretation of rape in her 1975 book Against Our Will and other interventions at the time, women's movements throughout the world have directed our attention towards female victimisation and have offered a gendered analysis of the reason such victimisation exists and why governments have not done more to combat such victimisation. Since the book's publication, rape and other forms of sexual harm have become thoroughly associated with male perpetration and female victimisation; such acts have been interpreted not only as attacks on individual women but also as attacks on women as women. Most of the chapters in the present book are influenced by such understandings of rape 


\section{May-Len Skilbrei et al.}

as a social phenomenon, with causes and effects which reach far beyond the people who are directly affected by such acts.

Female perpetration and male victimisation continue to be less debated and researched than other forms of rape. Police statistics continue to represent rape mainly as something that men subject women to. Now that we are aware of the problems of building our understanding of the phenomenon on figures that easily reproduce what is already taken to be true (and therefore are more easily identified and reported), calls to open debates and research to cover male victimisation have grown stronger (see Javaid, 2018; United Nations, 2018). While most of the examples covered in this book offer analyses of various aspects of male perpetration and female victimisation, some of the chapters also present discussions of the consequences gender has for how we understand rape.

While rape in many countries is defined as a physical assault and is often seen as a particularly harmful form of sexual violence, research in many contexts has demonstrated that treating rape as separate from other acts is problematic for two reasons. First, sexual harm is represented along a continuum, where the severity of the acts differs but shares key factors and consequences (Basile, 1999; Salfati \& Taylor, 2006). Second, research demonstrates that to separate rape from other acts and crimes is difficult for the people involved, including witnesses and police, which means that to sharply separate rape from 'rape-like' or 'grey zone' acts means that we miss a great deal of information about why and how rape occurs.

Following this notion, the present book is about rape in the wider context of other types of sexual harm. The need to understand rape in a wider context, where other sexual and violent acts are not easily separated from rape, is also important in light of how rape itself is a highly contested issue (Conaghan, 2018; Reitan, 2001). The meaning of the concept has changed historically and varies across and within countries. Different and conflicting conceptualisations may co-exist and cause confusion about the boundaries of the phenomenon, for instance, when legal and lay understandings are different. Rather than departing from one authoritative definition of rape, the authors in this book explore rape as a contextually and historically situated occurrence and offer insight into the complexities of addressing the issue for those affected, both in research and at the societal level. This approach also means that we include other forms of sexual violence or assault than rape in the book, including phenomena located in the 'grey area' between rape and sex (Gavey, 2013).

These developments and controversies create a need for research. Because debates feed on numbers, a key topic of research to date has been the development of better tools to assess the scale of the problem and to understand more about who is affected, and why. The fact that those in the field have difficulties in agreeing on definitions and perspectives implies that we also require the discursive means to understand the problem and those affected, as well as the responsibilities of societies to confront the problem. At the same time, these same characteristics place great responsibility on researchers to be very clear about their theoretical positions and the limitations of their findings, and to 
ensure that their findings are not misrepresented in ongoing debates. While clear transnational and global trends exist in how rape is understood, approached, and researched, we argue that the necessary methodological, theoretical, and epistemological development of the rape literature needs to be grounded in national and regional manifestations in the form of concrete empirical studies. This book is an attempt to explore methodological, theoretical, and epistemological issues, using the case of rape in the Nordic countries as a starting point. In this way, the book's authors offer insights into the literature and on continuities and change in the Nordic context.

\section{The Nordic context}

The Nordic region is a particularly interesting case for the exploration of rape and other forms of sexual harm as both a personal and a socio-political issue. For several decades, the region has often been portrayed as being 'best in its class' in ensuring equality and social protection to its population. The Nordic countries are generally associated with a strong welfare state - what Gøsta Esping-Andersen in 1990 termed the 'social democratic welfare regime' - and the merits of this way of organising society and state-citizen relations continue to attract international attention (McKowen, 2018). As mentioned above, women's movements in the last few decades have offered an analysis of rape as something that is caused by and has consequences for much more than the people who are directly involved in a given case of rape. This situation has meant that policies that were designed to assure greater gender equality are also widely thought to serve to prevent rape and other forms of sexual harm. This link has also been made in the Nordic countries, and the institutionalisation and success of the region's gender-equality policies have received international praise (Borchorst, 1999). The Global Gender Gap Report (World Economic Forum, 2018) from 2018 places Iceland, Norway, Sweden, and Finland in the top four positions (in that order), while Denmark is in 13th place. Not only is gender equality something that the individual Nordic countries have strongly emphasised over the last few decades; ensuring gender equality has also been prioritised and harmonised at the regional level, through strong collaborations between the various countries on several platforms. The Nordic Council of Ministers, for instance, sees gender equality as a 'key area of co-operation for the Nordic countries'.

The fact that the Nordic countries are generally, but not uniformly, oriented towards gender equality is often presented as the result of an alliance between feminism and the state and as an alignment of the concerns of civil society and the state. The alliance and alignment between feminism and the state are expressed by Helga Hernes's term 'state feminism', from her 1987 book Welfare State and Woman Power: Essays in State Feminism. This link secures support and disciplines the state into mainstreaming gender into the state's various policy areas and governmental branches. This situation is often considered a feminist victory, but what is less often discussed is how this alliance and alignment have also disciplined feminist activists in how they prioritise causes 
and protest. A central aspect of Nordic feminism is that it has very explicitly turned to criminal law as an instrument for achieving gender equality (Burman, 2010), and acts such as rape are commonly viewed as the result and expression of gender inequality but also as an attack on and something that is detrimental to gender equality.

To investigate rape in the Nordic countries is thus also to investigate the foundation and consequences of Nordic gender equality. The Nordic countries are often presented as a coherent region in terms of welfare orientation, statecitizen relations, and gender equality. At the same time, great differences exist between the five Nordic countries, both in the centrality of gender equality as a stated goal and in how the individual countries approach rape and other forms of sexual harm. To draw together analyses from all the Nordic countries therefore invites a comparison between contexts that, from the outset and from the outside, look very similar, but when looked at more closely, they have several important differences.

There are also other reasons to problematise the imagery of the Nordic countries as being uniform and consistent in their prioritisation of gender equality. Researchers have questioned whether the region really is special, or at least if it is still special (see Liinason, 2018; Witoszek \& Midttun, 2018). While the Nordic countries may not be as exceptional and uniform as they are often presented, ideas about Nordic coherence and the continuing prioritisation of gender equality are central to national identities in the region (de Los Reyes, 2017; Tham, Rönneling, \& Rytterbro, 2011). The Nordic Council of Ministers, for instance, presents gender equality as one of the aims of its collaborative efforts: 'Successful Nordic co-operation on gender equality can not only help us increase gender equality in our own region, but also help to ensure the strong profile of the Nordic region internationally on gender equality' (Nordic Council of Ministers, 2019, p. 5).

Gender equality policies are not the only internationally acknowledged side of the priorities and orientations of the Nordic welfare states. These nations are also known for humanitarian penal policies that stand in contrast to developments in many other Western countries in the last few decades. Low levels of punishment, penal innovations designed to protect vulnerable groups from the negative consequences of imprisonment, the widespread use of 'open' prisons, the existence of humane prison conditions, and an elaborate system of transition from prison to ordinary society have all earned the region a reputation for 'penal exceptionalism' (Pratt, 2008). While some (e.g. Ugelvik \& Dullum, 2011) have critiqued the conclusion that Nordic societies are less punitive and that punishments are more humane, the levels of punishment are low in relation to other European countries - with one notable exception, the punishment for sex crimes. In the last two decades, several of the Nordic countries have changed their rape legislation and punishment levels considerably. Denmark, Finland and Norway currently have similar formulations of the crime of rape in their penal codes, as they all emphasise violence and coercion (Jacobsen, 2019, p. 48), while Iceland and Sweden both revised their respective acts in 2018 to criminalise the lack of consent rather than the presence of violence or coercion. 
The willingness to punish sex crimes seems to make such crimes an exception to the Nordic or Scandinavian penal exceptionalism (Tham, 2001). The position of the women's movements in the region and the strength of women's political mobilisation and representation (for an analysis, see Borchorst \& Siim, 2008) are also relevant sides of the context. In their priorities, the women's movements have expressed what the criminologist Kristin Skjørten (1996) has called 'legal optimism', i.e. an overly strong belief in what criminal law can accomplish. One could argue that the low thresholds of sex-crime legislation and the breadth of acts that are criminalised as sexual harm were enabled by decades of feminist investment in changing understandings of the relationship between public and private and between the state and its citizens. Matters that are typically considered private elsewhere are more often treated as being within the scope of the state in the Nordic countries (Borchorst \& Siim, 2008).

Bearing in mind the great investments that have been made in the Nordic countries to counteract sexual harm and to establish gender equality, it appears paradoxical that phenomena such as rape continue to pose a challenge to policy-makers. Figures of police-reported rape and figures from populationbased surveys indicate that rape affects a considerable part of the population in the Nordic region (Heinskou, Schierff, Ejbye-Ernst, Friis, \& Liebst, 2017; Swedish National Council for Crime Prevention, 2017; Thoresen \& Hjemdal, 2014). The number of cases of rapes reported to the police has increased in the region, with the increase particularly evident in Sweden. Because Sweden, in many areas, has what is often considered the most progressive policies on gender equality, but also on sexual violence, in the region, it also appears paradoxical that the nation consistently shows higher figures for reported sexual victimisation than the other Nordic countries (Tham et al., 2011, p. 587). While this situation does not mean that levels of victimisation in society are higher or increasing, the increase in registered numbers of rape in the Nordic region has attracted attention internationally (see, for example, Fox News, 2017).

The Nordic approach to rape also shows other paradoxes. While people in the region have paid attention to the power and role of law in combatting rape, they have paid less attention to the issue of which other steps can be taken to prevent rape and to promote desistance among perpetrators. Services are available for both victims and perpetrators that may also serve to prevent trauma, revictimisation, and re-perpetration, but such services are not comprehensive and systematic throughout the region or within each country. One may suspect that this is a case where criminal justice approaches have been prioritised and that they often overshadow other policies.

For these and other reasons, rape and other forms of sexual violence are currently high on public agendas throughout the Nordic region, especially in Denmark, Norway and Sweden. Fears over high figures and high levels of attrition through the criminal justice process are often debated in terms of a need for legislative revisions. Overall, ideas about rape and sexual violence and the appropriate responses to these issues seem to be changing in interesting ways in this region. While changes are also happening elsewhere in Europe, there are 
reasons to consider the ongoing changes within the Nordic region as being related to each other and linked to broader developments in terms of penal cultures, welfare state retraction and expansion, gender equality policies, and public-private partnerships.

These factors make this a particularly important time to look at rape in the Nordic countries from different angles. Based on this background, the authors in this book illuminate the phenomenon and construction of rape and other forms of sexual harm within the Nordic region, as well as on how they are addressed through social policies and in legal systems. The aim is to fertilise both the international scholarship on sexual violence and the scholarship on the Nordic region. The chapters in this book have been arranged based on our ambition to cover a broad area. The structure and content of the book will be described in greater detail below; first, a note on terminology.

\section{A note on the 'victim' label}

In a recent article on the social risks of labelling, telling and reporting sexual assault among college students in the USA, Khan, Hirsch, Wamboldt, and Mellins (2018) caution against understandings of rape that are organised around identity categories such as 'survivor' and 'perpetrator', as 'such words suggest a kind of person rather than an act or experience' (p. 453). And further, because these words encompass so much they 'may serve as impediments to people making sense of their experiences or getting the kinds of help that they need' (p. 453). Their point is that there is not a one-to-one relationship between experiencing rape and taking up a survivor or victim identity; rather, people who experience rape will often shy away from these labels and associated identities. We can infer from this idea that researchers should focus on the experience of rape rather than on the person who has been raped. The authors draw a parallel to how the phrase 'men who have sex with men', which was coined by HIV activists two decades ago, makes no assumptions about the sexual identity among this group of men but simply describes a sexual practice. This line of argument also points to the political aspect of labels and concepts, and to how labels that describe experiences rather than identities may contribute to the removal of stigma. Another example could be the shift from talking about crippled or disabled people to talking about people with disabilities.

Khan et al.'s (2018) position could be viewed as being rather radical in the general rejection of what they see as identity labels. Other researchers (for an overview, see Hockett \& Saucier, 2015) do not problematise identity labels as such but do favour one over the other: most often the 'survivor' label or the combined 'survivor/victim' construction over the 'victim' label. These researchers' argument is that the 'victim' label, as an identity label, signifies something weak, fundamentally broken and powerless. The term 'survivor' is typically applied to encompass the serious ramifications of sexual violence but also to empower those who are affected (see, for example, Williamson \& Serna, 2018). 
Labels matter, of course, not only in the sense that they are problematic to their holders but also by how they have implications for problem understandings and decision-making related to solutions. The editors of this book have not instructed the authors to apply a particular terminology; the authors have applied concepts and labels that fit with the aims and materials of their particular chapters. In the chapters on law and the penal process, the parties involved are thus labelled according to their status in the case, for example, as the 'complainant' and the 'assailant' or 'accused'. In other chapters, the authors use different labels, and in some chapters, they avoid labels altogether.

Taken together, the chapters demonstrate that default political and perhaps ethically motivated positions on labelling people who are involved in rape and other forms of sexual assault are problematic. The victim label may mean and do different things within different frameworks. From some perspectives, the victim label makes sense and is productive, while from other perspectives, it is problematic. Researchers should therefore be mindful of the broader framework and positioning of their studies and how different labels fit their particular scholarly projects.

\section{The content of the book}

This book is designed to represent the whole Nordic region and to take up topics that are particularly timely in the region and beyond. The specific context of the Nordic region needs to be taken seriously. At the same time, the authors also demonstrate that Nordic experiences have shown that some themes and developments are more general, rather than being particularly Nordic. We believe the readers of the book will be struck by the similarities between the region and elsewhere in terms of the manifestations, policies and debates on sexual violence. The book offers new research on perpetrators, victims, criminal justice and prevention, and at the core of the theoretical discussions in the book are issues such as consent, power, sexual ethics, boundary making and victimhood and perpetrator constructions. The chapters speak to the great interest in delineations and definitions (and therefore also in attempts to estimate the extent of victimisation) as well as the challenges that digitalisation poses to efforts to prevent, detect and prosecute rape and other forms of sexual harm.

The book addresses four key sets of questions related to rape and other forms of sexual harm. The first is theoretical and methodological questions related to how we can understand and study rape; the second is the role of criminal law; the third how we can best understand perpetrators; and the fourth is the role, character and consequences of the digitalisation of rape and other types of sexual harm.

\section{Part 1: understanding, delineating and studying rape}

The first part consists of four chapters that in different ways address questions of how rape is studied. A key question in both political debates and scholarship 
is how rape can be appropriately defined and delineated from other acts and situations. Ideas about rape have never been constant. Reconceptualisations of rape have a long history, from rape being a property crime that men commit against other men - i.e. the theft of their women's sexuality or honour (McGlynn \& Munro, 2010, p. 1) - to an affront to women's modesty, to the sexual integrity and freedom arguments that today are central in international fora but also within many other jurisdictions. The definition of rape as an attack on the person is thus a rather new construction.

Based on this background, Conaghan (2018) has argued that the manifold ideas about what rape is, why it happens and the harm it causes make it impossible to talk about an essence of rape, a constant across time and space. Other scholars have taken a different position, arguing that rape can be distinguished from other sexual acts by different normative criteria, most commonly by referring to rape as an undermining of sexual autonomy or integrity (see, for example, Cahill, 2001). This notion means that the improvement of our capacity to study rape is also a thoroughly theoretical endeavour when addressing questions that initially appear practical in nature. The chapters in this part of the book offer inroads to further our understanding of how rape and other forms of sexual harm can be understood as being produced by and located in the social - in relations, situations, and cultures.

The first chapter in this part of the book investigates how theories of gender are applied in the study of sexual violence within intimate relations. Margunn Bjornholt is the author of the chapter 'Theorising sexual violence in intimate relations in Scandinavia: A literature review', which focusses on the theoretical frameworks that have informed empirical research on sexual violence in the Scandinavian countries to date, with the aim of mapping out a landscape of theoretical positions. Her starting point is that although a given research field may be international, theorisation also occurs in the national and regional contexts where scholars live, work, and think. The chapter provides analyses of five recent publications by Danish, Norwegian, and Swedish authors representing different key positions. The review reveals the theoretical diversity and innovation in making sense of sexual violence among Scandinavian scholars, as well as the continued relevance and theoretical potential of a renewed involvement with different strands of feminist theorisation.

The theoretical exploration in Bjørnholt's chapter is followed by a chapter by Monika Rosten titled 'Cultivating ethical negotiations or fetishising consent in BDSM?', which addresses bondage, discipline (or domination), sadism and masochism. In this chapter, Rosten explores negotiations about consent in the BDSM context. Ideal BDSM play is based on consent. The parties establish agreements about roles and transgressions and their absolute boundaries. Rosten analyses a case that started out this way, but where the dominance play escalated to encompass most of the everyday life of the submissive partner, Tina. Tina was conflicted about the relationship and how she had consented to being dominated in ways that were impossible to escape, and she wondered if she had been exposed to partner violence rather than BDSM play. This case led Rosten 
to further investigate the boundaries of consent as she interviewed other BDSM practitioners. Her analysis reveals how consent is fetishised in the BDSM community in ways that make it possible to see how unequal power relations play into seemingly sound negotiations and relationships.

The difficulties in delineating between sexual violence and legitimate sexual acts are followed up in Chapter 4, 'Understanding unwanted sexual touching: A situational approach'. In this chapter, Kari Stefansen explores the phenomenon of unwanted sexual touching, arguing that the topic provides insight into the boundaries of sexual violence. Using written descriptions of unwanted sexual touching from young women (18- to 19-year olds) drawn from a survey study, she demonstrates the unstable and fleeting character of unwanted sexual touching. Such touching takes on different meanings in different social situations and is also dependent on the relationship between the people involved: sometimes an aggressive act, at other times unwanted. Stefansen argues that incidents of unwanted touching are problematic even when they are not experienced as being sexual intrusions, as they may contribute to a diffuse 'phenomenology of fear' among girls and women: the embodied knowledge that their right to bodily integrity is less protected than that of boys and men.

The three chapters taken together illustrate well the instability of the term 'rape' and the difficulties involved in separating rape from the characteristics of relationships, situations, and contexts. This instability makes empirical research very difficult, not least when depending on people's own definitions and delineations when undertaking surveys to produce knowledge on the extent of rape. In Chapter 5, 'Making the case for 'good enough' rape-prevalence estimates: Insights from a school-based survey experiment among Norwegian youths', Kari Stefansen, Mette Løvgren and Lars Roar Froyland illustrate some of the difficulties in measuring rape in population surveys. As Krebs (2014) has done, they argue for a dual approach to rape-prevalence estimates: that researchers should pursue both 'best' and 'good enough' procedures. Their own analysis addresses rape estimates based on survey studies among youths in the school setting. Drawing on a survey experiment that was set up within a Norwegian school-based study, they conclude, in line with international scholarship, that wording is crucial and that the asking of behaviourally specific questions leads to higher rates of rape than the use of general questions, which holds for both genders and for different social groups. They argue that among youths and for the purpose of tracking developments in the prevalence of rape over time, simpler 'good enough' measures are indeed useful.

\section{Part 2: the formulation and role of criminal law}

Changes over time in how rape is delineated, explained and discussed shift which approaches seem just and sustainable. If rape is seen as something that exists due to a combination of male sexual drive and lack of self-discipline, then doing something about either or both of these factors may seem like a viable solution. If one instead regards rape as an act that is committed due to 
a perpetrator's own psychological trauma or disposition, then therapy will appear to be a sound way forward. Criminal law operates at the nexus of both explanations. The law defines the conditions under which an individual is culpable, but the reasoning behind something being defined as a crime may still be built on an understanding of the act being premised on particular ideas about sexuality, gender and power inequalities. Several of the chapters in this book address legal responses to rape in the Nordic countries, which is an important strand of Nordic scholarship on rape: something that perhaps reflects that legal strategies have long been the priority of both Nordic governments and of women's movements. But how criminal law defines and penalises rape and other forms of sexual harm has been a key focus for political and scholarly debates in many European countries, as is evident in ongoing discussions about whether the harm of rape is best expressed by criminalising the presence of violence and coercion or the lack of consent. Several authors address how criminal law addresses rape and other forms of sexual harm. While criminal law typically positions the perpetrator in the centre of the criminal justice process, the last few decades have seen powerful protests against the invisibilisation of the victim. As a result, victims' rights in the criminal justice process have changed substantially since the 1990s, both in the Nordic countries and in many other contexts.

Part of the question of how to define rape is the question of who can be raped. In many countries, sexual violations that take place within marriage are exempt from the definition of rape, either in the law itself or in practice. One priority of 1970s feminism was to bring violations that take place in the home to the attention of politicians and to make sure that such crimes were illegal, on par with physical and sexual crimes that take place between strangers (Skjørten, 1996). Riikka Kotanen's chapter, 'From the protection of marriage to the defence of equality: The Finnish debate over the sexual autonomy of wives', addresses this issue by investigating the process and debates that led to a universal rape prohibition in Finland in 1994. She looks particularly at how debates emerged and played out and then places these debates in the larger Nordic context, concluding that Finland was particularly late in recognising the sexual autonomy of wives. Kotanen discusses possible reasons that a marriage exemption in rape law was widely seen as legitimate in Finland, and she points to how feminist campaigners in the end managed to shift this understanding. This chapter thus explores a legal reform two decades in the making and looks at the interaction between the law-revision process, ongoing public debates and the role of the sanctity of family and home in Finnish culture.

At the end of Kotanen's chapter, she points to emerging debates in Finland about the revision of rape law to criminalise the lack of consent. Such revisions have been debated throughout the region, not least after Sweden revised its own act on the subject in 2018. The Nordic countries frequently collaborate on gender-equality issues and often look to each other when designing their own national approaches. In the chapter 'Towards voluntariness in Swedish rape law: Hyper-medialised group rape cases and the shift in the legal discourse', Gabriella Nilsson analyses the trajectory of Swedish debates on rape law in the 
period 1990-2015. This was a period in which rape law underwent major revisions designed to solve problems in prosecuting rape as well as in expressing understandings of the harm of rape. A long line of revisions has also taken place in several of the other Nordic countries, which demonstrates both a political willingness to look for better solutions and uncertainty in how to best define rape. In Nilsson's analysis of the particular case of Sweden, she finds that the debates that have followed after particularly attention-grabbing cases of rape seem to have affected debates about rape legislation, and later reform, throughout the period. The chapter therefore highlights the role of the media and how concerns about rape have been energised by fear of migrants and by the future of a sustainable welfare state.

Over the last few years, Sweden and other countries have witnessed several debates about the question of which definition of rape is most appropriate, both in the practical and symbolic senses. The Nordic countries have all signed the Council of Europe Convention on preventing and combating violence against women and domestic violence, which explicitly describes rape as a situation with a lack of consent. Current debates revolve around whether consent-based laws or coercion-based laws can better encompass how power affects sexuality and personal relations. Helena Jokila and Joanna Niemi discuss this debate in their chapter 'Rape law and coercive circumstances', in which they problematise the assumption that consent-based rape law will solve the current problem many countries face in their ability to prosecute rape. Jokila and Niemi analyse selected rape cases from the Finnish Courts of Appeal and compare them with Canadian convictions; in doing so, they demonstrate that evidentiary questions and considerations for the most part are the same across jurisdictions. The authors argue that attention should be directed towards ways of making rape laws include contextual factors, and they point to how rape laws can be thoroughly revised by looking to definitions applied in the International Criminal Tribunals for Rwanda and for the former Yugoslavia.

Paying attention to law not only involves looking at how the perpetrator in cases of rape is investigated and punished; such attention also entails looking at how the injured party, the victim, is treated throughout the criminal justice process. Hildur Fjóla Antonsdóttir's chapter in this book, 'Empowered or protected?: The 'problem' of complainants' rights in Danish and Norwegian preparatory works on criminal procedure', analyses how victims and victims' rights are represented in Danish and Norwegian preparatory work, including hearing procedures. As mentioned above, the victim's role in the criminal justice process is mainly to serve as a witness for the prosecution. The last two decades, however, have seen victims gaining more rights to be active parts of the process. This change has been received differently in various contexts, and Antonsdóttir demonstrates that such differences in views have also been expressed within the Nordic region. She finds that while Norwegian preparatory documents' discussions of increasing rights to participation and inclusion for victims have mainly been framed as empowering victims (and thus realising their citizenship rights), the Danish documents frame such discussions as a threat to 
the rule of law and to the victim. Antonsdóttir argues that one reason for this situation is that the injured party is mainly treated as a citizen in the Norwegian documents but mainly as a victim in the Danish documents. In this case, being defined as vulnerable and in need of the state's protection makes the receipt of full inclusion difficult for victims.

\section{Part 3: perpetrator and perpetration constructions}

Research on rape often focusses on the people who are subjected to rape and investigates the phenomenon from their perspective. While there are good reasons for considering what rape entails for victims to be a key topic in research (Alcoff, 2018), we argue that the field needs more investigations of the perspectives of perpetrators. For long periods in history, and in diverse geographical places, rape has been defined as a matter of male sexual urges (see, for example, Fradella \& Fahmy, 2016). In this understanding, rape is a matter of men acting on a biological disposition. This understanding does not mean that, in such periods, rape has been defined and treated as inevitable, in the sense that perpetrators have been exempt from blame and punishment. During such periods, the reactions from others and from the authorities are typically based on condemnation of the lack of ability to control one's urges in the perpetrator, having committed a crime due to lack of self-discipline.

More psychologically based explanations became important at the end of the 19th century. In this perspective, rape and other forms of sexual violations came to look like crimes linked to psychological trauma and disposition; treatment and incapacitation, depending on how deterministic the diagnoses were, appeared to be the most viable solutions. Not least as a result of various feminist campaigns, the last four decades have seen rape turned into a matter for sociological interpretation, where the reasons are sought in gender relations, power dynamics, and sexuality constructs. This change does not mean that biological and psychological explanations have disappeared but that they are complementary and competing, depending on the characteristics of the crime and on the context.

This book includes several chapters that specifically discuss situations where sexual violations, including rape, occur. Two of these chapters are included in part 3 , as they address norms that inform how perpetrators reason. The shifts in interpretative frameworks described above also inform more lay reasoning on how committing rape and other forms of sexual harm is related to existing norms and other acts. Individualistic psychological explanations easily end up positioning the rapist as someone who is in breach of normative masculinity and sexuality, while more sociological understandings frame rape differently. It is easy to see that such shifts in our understanding of why someone commits rape mean that during some periods, the act looks like a continuation of normative masculinity and social relations, while during other periods, such acts constitute a breach with the norms and practices of masculinity.

In Chapter 10, 'Othering the rapist: Rurality, sexual violence and the Bjästa case', Lucas Gottzén and Anna Franzén explore such normativity based on 
an empirical study of the implementation of a school-based preventive programme. In this programme, students were presented with a concrete case of sexual violence that they then discussed with their teachers in class: the Bjästa case. The programme that Gottzén and Franzén studied particularly thematised gender and bystander responsibility. The authors found that the meanings the students drew from the programme were different from what it was designed to do. Instead of utilising the case presented in the programme to reflect upon normative sexuality and gender, they instead distanced themselves from the case. This distance was possible due to how rurality holds a particular meaning, and the students explained what happened in the case by how, in the rural community in question, the perpetrator and the community were different from what the students considered to be the norm. This outlook meant that the programme reinforced the students' stereotypes about places and people rather than enabling them to reflect on rape and individual responsibility in the face of rape.

While sociological explanations of why rape occurs often emphasise how the act of rape is best understood if we relate rape to acts that are legal and legitimate, it is easy to understand resistance to an association between one's own actions and relations with rape. In Chapter 11, 'Sexual transgressing: Situational and narrative perspectives', Laura Marie Schierff and Marie Bruvik Heinskou investigate situational descriptions of sexual transgressions from the perspective of the transgressor. The authors conducted qualitative interviews with young men who, in their own words, had committed sexual transgressions. Based on the men's descriptions of the situations where these acts had occurred, the authors discern situational logics or patterns that may help us understand why these acts occurred. Schierff and Heinskou present accounts of situations and explore what these accounts, or narratives, do for how the transgression is understood. The first account is a framing of the transgression as the result of alcohol intoxication, which means that the men positioned themselves as not being themselves in the situation. The second narrative explains the transgression by misunderstandings of the signals of consent and the absence of consent.

While both explanatory narratives are also excuses, it is valuable to take them seriously as narratives that enabled the men to integrate what they had done without such integration necessarily changing how they looked at themselves. Understanding such mechanisms is important if we are to understand why rape and other types of sexual harm are committed, but also why perpetrators, victims, and bystanders do not necessarily acknowledge such transgressions as something that should be acted upon.

\section{Part 4: the digital dimension}

The fact that more and more areas and aspects of life have become digitalised poses challenges to the definition, detection, and prosecution of sexual violations, including rape. The book includes three chapters that illustrate this development. The first chapter in part 4 examines how online abuses challenge traditional ideas 
and approaches to the phenomenon of rape, the second analyses the importance of digital arenas for perpetrator dynamics, and the third explores the role and structure of online disclosures of rape and other types of sexual harm. All three chapters address thresholds in one way or another: thresholds for how society, perpetrators and victims recognise acts as problematic.

Acts of sexual exploitation and abuse that happen online and via mobile phones have gained a great deal of attention in recent years. Such cases are also beginning to reach European courtrooms. Chapter 12 presents one such case. In the chapter 'Rape in the age of the Internet', Elisabeth Fransson, Trond Martinsen and Elisabeth Staksrud analyse a case where a young man named Alex is convicted of over one hundred counts of rape that took place via the Internet and mobile phones. He manipulated, and later threatened, young people into sharing pictures and engaging in sexual acts in front of a camera that they themselves controlled. The fact that the perpetrator and the victims did not meet and that the acts did not physically involve Alex was challenging to handle within the scope of existing law and case law, but this case entailed a careful translation of meaning and consequences from more traditional accounts of rape to digital arenas. Alex, his victims, and the court all struggled with how to understand and react to what had happened, and while Alex acknowledged that his acts were problematic, he was unable to free himself from an understanding of rape as something that involves direct physical threats and sexual encounters. This chapter thus adds to the literature on rape both by presenting an analysis of a development that is quite new and by illuminating something that also happens in other cases: namely that the situations and relations in which abuses occur may look very different for the various people involved.

The fact that situational factors affect how rape and other forms of sexual harm are interpreted and reacted upon is not surprising, but what mechanisms are involved? In Chapter 13, 'Digital sexual violence: Image-based sexual abuse among Danish youth', Sidsel Kirstine Harder, Katrine Elmose Jørgensen, Jonathan Priesholm Gårdshus and Jakob Demant analyse the mechanisms behind the non-consensual sharing of sexual images by building on a combination of survey and qualitative data among young Danes. Image-based sexual abuse has been the subject of much attention in the last few years, and the laws, technologies and understandings of the subject are changing. Few empirical investigations into the phenomenon have been conducted to date, however. The authors look to criminological theory to investigate what creates the likelihood of sharing such pictures. They find that poorer self-control is associated with a higher risk of committing image-based sexual abuse, although the effect is moderate and partly mediated through digital, sexual and social opportunities. The chapter offers insights that are important for understanding why such picture sharing takes place, which may help to prevent such activities in the future.

Digitalisation thus may lower thresholds for committing violations and could transform the expression of such crimes. Digitalisation is also a development that affects victims' courses of action. A key theme in the literature on victimisation is that there are many barriers to self-identification as a victim of rape 
and other forms of sexual harm and to disclosing such experiences to others. In Chapter 14, 'Breaking the silence: Social media disclosures of sexual violence in Iceland', Rannveig Sigurvinsdóttir, Bryndís Björk Ásgeirsdóttir and Sara Arnalds explore how online disclosures of rape and other forms of sexual harm play out. They empirically studied the trajectory and content of particular exchanges that took place on online platforms at the same time that particular events and debates were also taking place and being presented in traditional media. The authors analyse this scenario in relation both to what was being disclosed and what reactions these disclosures attracted from other participants within these arenas. They find that patterns of disclosure followed public debate and that those who disclosed received much support, but often the support was of little substance. It is important to understand how the characteristics of online platforms affect disclosure and the relationship between such disclosures and those that take place face-to-face. Does online disclosure serve a similar purpose, or should it instead be understood as a political act of participation in an event? This chapter contributes knowledge to the development of online arenas that can serve as platforms for sharing experiences with violations as well as to the mechanisms that hinder and facilitate disclosure more generally.

We invite readers to delve into these chapters with an open mind in order to understand the various implications that rape has in our modern society, both in the Nordic context and abroad.

\section{Note}

1 www.norden.org/en/information/nordic-co-operation-gender-equality.

\section{References}

Alcoff, L. (2018). Rape and resistance. Cambridge, UK: Polity Press.

Basile, K. C. (1999). Rape by acquiescence: The ways in which women 'give in' to unwanted sex with their husbands. Violence against Women, 5(9), 1036-1058.

Borchorst, A. (1999). Ligestillingsinstitutionerne. In C. Bergqvist, A. Borchorst, A. D. Christensen, N. C. Raaum, \& A. Styrkásdóttir (Eds.), Likestilte demokratier? Kjønn og politikk $i$ Norden (pp. 156-175). Oslo: Universitetsforlaget.

Borchorst, A., \& Siim, B. (2008). Woman-friendly policies and state feminism: Theorizing Scandinavian gender equality. Feminist Theory, 9(2), 207-224.

Brownmiller, S. (1975). Against our will: Men, women and rape. New York: Fawcett Columbine.

Burman, M. (2010). Rethinking rape law in Sweden: Coercion, consent or nonvoluntariness?. In C. McGlynn \& V. E. Munro (Eds.), Rethinking rape law: International and comparative perspectives (pp. 196-208). New York: Routledge.

Cahill, A. J. (2001). Rethinking rape. Ithaca, NY: Cornell University Press.

Conaghan, J. (2018). The essence of rape. Oxford Journal of Legal Studies, 39(1), 151-182.

de Los Reyes, P. (2017). When feminism became gender equality and anti-racism turned into diversity-management. In L. Martinsson, G. Griffin, \& K. G. Nygren (Eds.), Challenging the myth of gender equality in Sweden (pp. 23-48). Bristol: Policy Press. 
Esping-Andersen, G. (1990). The three worlds of welfare capitalism. Cambridge, UK: Polity.

Fox News. (2017). Trump may have been unclear, but Sweden experiencing a migrant crime wave. 20 February 2017. www.foxnews.com/politics/trump-may-have-beenunclear-but-sweden-experiencing-a-migrant-crime-wave (accessed 20 April 2019).

Fradella, H. F., \& Fahmy, C. (2016). Rape and related offences. In H. F. Fradella \& J. M. Sumner (Eds.), Sex, sexuality, law, and (in)justice (pp. 138-182). New York: Routledge.

Gavey, N. (2013). Just sex? The cultural scaffolding of rape. London and New York: Routledge.

Heinskou, M. B., Schierff, L. M., Ejbye-Ernst, P., Friis, C. B., \& Liebst, L. S. (2017). Seksuelle kraenkelser i Danmark: Omfang og karakter. Copenhagen: Det kriminalpræventive råd.

Hernes, H. (1987). Welfare state and woman power: Essays in state feminism. Oslo: Norwegian University Press.

Hockett, J. M., \& Saucier, D. A. (2015). A systematic literature review of 'rape victims' versus 'rape survivors': Implications for theory, research, and practice. Aggression and Violent Behavior, 25(Part A), 1-14.

Jacobsen, J. (2019). Valdtektsstraffebodet: Gjeldane rett og spørsmålet om reform. Bergen: Fagbokforlaget.

Javaid, A. (2018). Male rape, masculinities, and sexualities: Understanding, policing, and overcoming male sexual victimisation. Cham: Palgrave Macmillan.

Khan, S. R., Hirsch, J. S., Wamboldt, A., \& Mellins, C. A. (2018). 'I didn't want to be "that girl": The social risks of labeling, telling, and reporting sexual assault. Sociological Science, 5, 432-460. doi:10.15195/v5.a19

Krebs, C. (2014). Measuring sexual victimization: On what fronts is the jury still out and do we need it to come in? Trauma, Violence, \& Abuse, 15(3), 170-180.

Liinason, M. (2018). Equality struggles: Women's movements, neoliberal markets and state political agendas in Scandinavia. Abingdon, UK: Routledge.

McGlynn, C., \& Munro, V. E. (2010). Rethinking rape law: An introduction. In C. McGlynn \& V. E. Munro (Eds.), Rethinking rape law: International and comparative perspectives (pp. 1-14). New York: Routledge.

McKowen, K. (2018). A welfare 'regime of goodness'? Self-interest, reciprocity, and the moral sustainability of the Nordic model. In N. Witoszek \& A. Midttun (Eds.), Sustainable modernity: The Nordic model and beyond (pp. 119-138). Abingdon, UK: Routledge.

Nordic Council of Ministers. (2019). Nordic co-operation programme on gender equality 2019-2022. Copenhagen: Nordic Council of Ministers. http://norden.diva-portal.org/ smash/get/diva2:1283606/FULLTEXT01.pdf (accessed 20 April 2019).

Pratt, J. (2008). Scandinavian exceptionalism in an era of penal excess. Part I: The nature and roots of Scandinavian exceptionalism. British Journal of Criminology, 48(2), $119-137$.

Reitan, E. (2001). Rape as an essentially contested concept. Hypatia, 16(2), 43-66.

Salfati, C. G., \& Taylor, P. (2006). Differentiation sexual violence: A comparison of sexual homicide and rape. Psychology, Crime \& Law, 12(2), 107-125.

Skjørten, K. (1996). Rettsoptimisme og seksualisert vold. Materialisten, 24(1-2), 21-39.

Swedish National Council for Crime Prevention. (2017). Kriminalstatistik 2016. Anmälda brott. www.bra.se/download/18.5484e1ab15ad731149e3a81c/1490859029793/Samman fattning_anmalda_2016.pdf (accessed 15 May 2019).

Tham, H. (2001). Law and order as a leftist project? Punishment and Society, 3(3), 409-426. 
Tham, H., Rönneling, A., \& Rytterbro, L. L. (2011). The emergence of the crime victim: Sweden in a Scandinavian context. Crime \& Justice, 40(1), 555-611.

Thoresen, S., \& Hjemdal, O. K. (Eds.). (2014). Vold og voldtekt i Norge: En nasjonal forekomststudie av vold $i$ et livsløpsperspektiv. Oslo: Nasjonalt kunnskapssenter om vold og traumatisk stress.

Ugelvik, T., \& Dullum, J. (Eds.). (2011). Nordic prison practice and policy: Exceptional or not? Abingdon, UK: Routledge.

United Nations. (2018). Report of the secretary-general on conflict-related sexual violence. www.un.org/sexualviolenceinconflict/wp-content/uploads/report/s-2018-250/SGREPORT-2017-CRSV-SPREAD.pdf (accessed 15 May 2019).

Williamson, J., \& Serna, K. (2018). Reconsidering forced labels: Outcomes of sexual assault survivors versus victims (and those who choose neither). Violence against Women, 24(6), 668-683.

Witoszek, N., \& Midttun, A. (2018). Sustainable modernity and the architecture of the 'well-being society'. In N. Witoszek \& A. Midttun (Eds.), Sustainable modernity: The Nordic model and beyond (pp. 1-17). Abingdon, UK: Routledge.

World Economic Forum. (2018). The global gender gap report 2018. Geneva: World Economic Forum. 